\title{
NOTAS SOBRE A PRESENÇA GUARANI NO ESTADO DO PARANÁ. Elementos de cosmologia e história*
}

\author{
Marcelo Caetano de Cernev Rosa
}

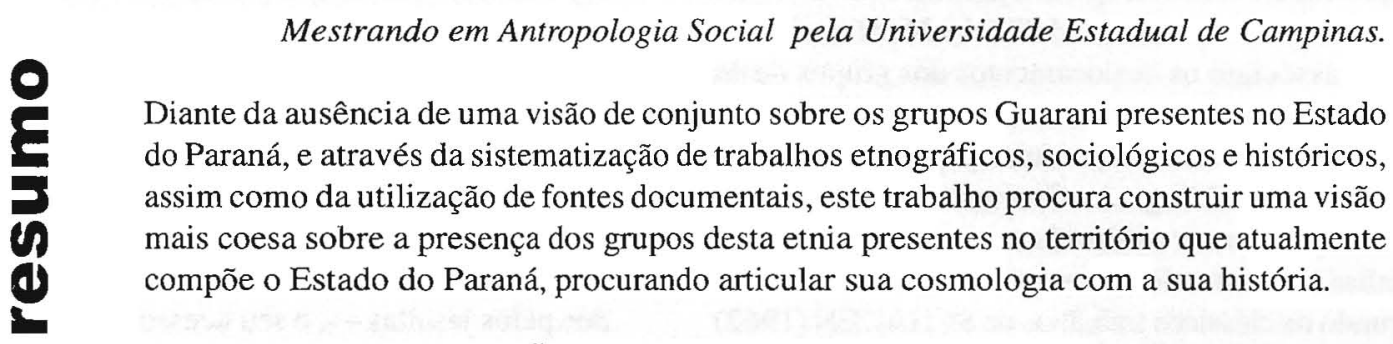

Palavras-chave: Guarani; Ñandéva; Kayová; Mbyá; Terra sem Mal; território.

\section{INTRODUÇÃO}

$\mathbf{O}$ s Guarani do Estado do Paraná, que atualmente constituem a segunda maior etnia indígena do estado, têm sido objeto de várias análises, com distintas preocupações e enfoques. Porém, podese perceber nesses trabalhos uma certa fragmentação no estudo desses grupos.

Esta fragmentação se dá à medida que determinados autores se debruçam sobre questões específicas e/ou ao estudo de grupos específicos sem levar em conta a necessidade de uma análise um pouco mais integrada.

Ela também se deve ao fato de que os trabalhos da maior parte dos historiadores prescindem de informações sobre a cultura Guarani, quando não de sua própria presença na história paranaense; e os estudos dos antropólogos não conseguem articular, satisfatoriamente, os dados da cultura com os da história. Tudo isto traz como consequiência uma certa insuficiência no que diz respeito a uma visão de conjunto sobre a constituição dos diferentes grupos indígenas no estado.

Visando contribuir para uma visão mais integrada sobre a presença Guarani no Paraná, em 1997 iniciei uma pesquisa reunindo dados históricos, etnográficos e documentais sobre os Guarani presentes neste estado, cuja primeira etapa possibilitou a produção de uma monografia intitulada
As parcialidades Guarani no Paraná: elementos de cosmologia e história. No presente artigo procuro sintetizar os resultados desta primeira etapa. ${ }^{1}$

Pertencentes ao tronco lingüístico Tupi e à família lingüística Tupi-Guarani, (RODRIGUES, 1984), os índios Guarani são classificados em três subgrupos:2 os Kayová, os Ñandéva e os Mbyá. ${ }^{3}$ Esta classificação corresponde a peculiaridades presentes em cada grupo, principalmente no que diz respeito à língua, à cultura material e também a alguns outros aspectos de sua cultura. Porém, todas essas constituem-se variações de um núcleo comum, ou seja, da própria cultura Guarani como um todo.

Segundo levantamentos recentes, na atualidade os Kayová concentram-se no Mato Grosso do Sul e no Paraguai. No Mato Grosso do Sul eles podem ser encontrados em áreas indígenas como Campestre, Limão Verde, Amambai, Caarapó, Dourados, Guaimbé, Guasuti, Jaguapité, Jaguari, Jarara, Panambi, Panambizinho, Pirakuá, Rancho Jacaré, Sassoró, Sete Cerros, Sucuriy, Takuaraty, Taquaperi, Cerro Marangatu e Lima Campo. (CEDI, 1996, p.721-723)

Os Ñandéva, além de estar presentes em áreas indígenas dessas regiões, também se encontram em áreas indígenas do Paraná, no Posto de Araribá (interior de São Paulo) e nas aldeias de Rio Silveira, Itariri e Bananal, localizadas no litoral paranaense.

Os Mbyá se concentram no leste do Paraguai, no Norte da Argentina, no Uruguai, no litoral dos estados do Paraná,

\footnotetext{
* O texto é uma adaptação da monografia intitulada As parcialidades Guarani no Paraná: elementos de cosmologia e história, apresentada como trabalho de conclusão do curso de Especialização em Sociologia e Sociologia da Educação, da UEL, em outubro de 1997, sob orientação da professora Kimiye Tommasino.
} 
Santa Catarina, Rio Grande do Sul, São Paulo, Rio de Janeiro e Espírito Santo e, ainda, numa área de reservas Guajajara no Maranhão. Cabe ressaltar que também estão presentes em algumas localidades do Tocantins e que existem grupos dispersos entre regiões do interior dos estados do Paraná, Santa Catarina e Rio Grande do Sul. (LADEIRA, 1992)

\section{ALGUNS ASPECTOS DA COSMOLOGIA GUARANI}

\section{A Terra sem Mal}

Logo que se pensa nos Guarani, as primeiras referências que vêm à mente dizem respeito à já consideravelmente popular "busca" pela "Terra sem Mal" (Yvy Marãey), à qual geralmente se associam os deslocamentos dos grupos desta etnia.

Todavia, cabe ressaltar que, apesar de ser algo relativamente comum na bibliografia Guarani, a concepção de Terra sem Mal precisa ser analisada com cuidado para que se evite analisá-la de uma forma muito reducionista.

Segundo os clássicos trabalhos de SCHADEN (1962) e de CLASTRES (1978), o termo Yvy Marãey significaria, na cosmologia Guarani, um local paradisíaco onde os homens não mais estariam sujeitos à morte, às doenças e nem mesmo às restrições socialmente estabelecidas. Sua localização geográfica se daria no sentido leste, além do oceano, constituindo este um obstáculo "natural", por assim dizer, ao seu acesso. Esta definição também é corroborada nos trabalhos de LADEIRA (1990; 1992).

Assim, na cultura Guarani, Yvy Marãey estaria em oposição à Yvy mba' emegua (a terra feia, má e/ou enganadora); a vida nesta última constituiria uma modalidade de existência também imperfeita, que denominam teko achy, ou seja, "vida doente". Como CLASTRES (1978, p.93) destaca, a vida na Yvy mba' emegua (a terra feia, má e/ou enganadora) seria imperfeita em virtude de duas razões: em primeiro lugar porque o homem é um ser que está destinado a morrer; e, em segundo, porque a sua vida é limitada por estar sujeita a uma série de leis ou regras socialmente estabelecidas.

Segundo SCHADEN (1962), apesar de toda a situação de contato dos Guarani com a sociedade nacional, e mesmo apesar da implantação das missões jesuíticas que procuraram e conseguiram aldear parte significativa dos grupos existentes naquela época (séculos XVI e XVII) os Guarani conseguiram manter uma mitologia própria.

Entretanto, ele destaca que houve algumas incorporações de elementos exteriores, oriundos da cultura ocidental, que conseqüentemente trouxeram significativas mudanças na mitologia do grupo, inclusive no que diz respeito à própria concepção de Yvy Marãey.

Schaden ressalta que, apesar de, aparentemente, a concepção de Yvy Marãey como um local paradisíaco a ser alcançado individualmente continuar inalterada na concepção do grupo mesmo depois da situação de contato, deve ser levado em consideração que tanto a forma como as razões de sua busca, bem como o momento no qual ela seria alcançada sofreram alterações significativas.

Em ambos os momentos, ou seja, antes e após a situação de contato, o acesso à Yvy Marãey no interior da cosmologia Guarani se daria através do aguydjê (da bemaventurança, ou estado de perfeição alcançado individualmente pelos homens que os colocaria, praticamente, em relação de igualdade com os deuses), obtido através de toda uma série de prescrições religiosas, mágicas e/ou morais. Através do aguydjê alcançar-se-ia o kandire (a imortalidade).

Anteriormente à influência ocidental, e sobretudo à influência da religião cristã, a possibilidade, no interior da cosmologia Guarani, de alcançar Yvy Marãey através do aguydjê apresentava-se como suscetível de se viabilizar durante a própria vida, ou seja, os Guarani poderiam alcançar Yvy Marãey sem ter que passar necessariamente pela prova da morte.

Posteriormente à situação de contato pode-se perceber que existe um certo deslocamento do eixo temporal, que, segundo SCHADEN (1962, p.162, 169 e 182), muito provavelmente advém das influências do cristianismo, de tal forma que a concepção de Yvy Marãey é mantida, mas, em determinados grupos - os que teriam sido mais influenciados pelos jesuítas - , o seu acesso tornou-se algo a ser concretizado somente após a morte.

Além disso, pode ser percebido no interior da cosmologia dos grupos Guarani que a busca de Yvy Marãey passou a se relacionar diretamente com a idéia de possíveis e prováveis destruições futuras da Terra, passando a representar simultaneamente o paraíso mítico, o local de refúgio para uma eminente "destruição do mundo" e, também, o local do restabelecimento dos costumes tribais que em grande parte já teriam sido "perdidos" ou "modificados".

Segundo Schaden, esses "novos aspectos" da concepção da Terra sem Mal teriam advindo da incorporação de alguns elementos cristãos que teriam sido reinterpretados no interior da cultura Guarani, como por exemplo, a noção de um "juízo final” e de uma conseqüente destruição da Terra e, também, da percepção, por parte do grupo, das conseqüências negativas que a situação de contato estaria trazendo à sua cultura. ${ }^{4}$

Como já foi dito anteriormente, os trabalhos de Schaden e de Clastres são considerados clássicos sobre a cultura Guarani; no entanto, é necessário que se estenda a discussão sobre Yvy Marãey até autores mais contemporâneos para que se possa compreendê-la de uma forma mais aprofundada.

Em seu recente trabalho, GARLET (1997) procura destacar a necessidade de atentar para outros significados que o termo Terra sem Mal possui, e que, em grande parte das pesquisas sobre as populações Guarani, não têm sido levados em consideração. Sinteticamente, pode-se dizer que o autor procura demonstrar como a academia tem privilegiado o aspecto mítico do termo, sobretudo no que diz respeito à sua utilização para explicar a mobilidade Guarani, relegando a um plano inferior as conjunturas histórico-sociais que certamente possuem um peso significativo nesses processos. Em suas palavras: 
"A maioria dos estudiosos preservou e/ou, simplesmente, transcreveu a expressão 'Terra Sem Males' (TSM), citada por NIMUENDAJÚ (...), para justificar tudo quanto se relaciona às migrações numa ampla abrangência temporal e espacial. (...) Percebe-se que, cada vez mais, o sentido e o significado da TSM assume uma dimensão ideologizada e metafísica, sendo projetada para uma esfera ideal e que prescinde da realidade e do espaço deste mundo físico e concreto. (...) o círculo acadêmico passou a ser o espaço privilegiado do mito." (GARLET, 1997, p.11-12)

Garlet procura destacar outros significados da Terra sem Mal, tentando demonstrar como ela não pode ser entendida como a única causa dos deslocamentos Guarani. Nesse sentido, ele destaca trabalhos como os de MELIÀ (1993) e MARTINEZ (1985), nos quais é possível perceber que a busca por uma Terra sem Males, muitas vezes, não significa "um local paradisíaco onde os homens não mais estariam sujeitos à morte, às doenças e nem mesmo às restrições socialmente estabelecidas" e cujo acesso se daria através do aguydjê, tal como fora exposto anteriormente, mas um local físico concreto: seria a terra boa, a terra que é produtiva, o espaço físico e social que possibilitaria a existência Guarani.

Em face às terras que historicamente os Guarani vêm perdendo pelo avanço da sociedade nacional, a Terra sem Mal pode muito bem significar faixas de terra nas quais, além das condições físicas adequadas, os Guarani possam estar ao menos distanciados da sociedade envolvente. "As migrações atuais teriam como alvo encontrar estes espaços da divina abundância dentro de um ambiente que está se deteriorando." (MELIÀ apud GARLET, 1997, p.493)

Dessa forma, é possível perceber que existe uma relação bastante importante entre a concepção de Terra sem Mal e a de território para os Guarani, à qual se retornará um pouco mais adiante.

\section{A concepção de território Guarani}

É necessário que se tenha bem claro que a concepção de territorialidade dos Guarani não corresponde à concepção dominante na sociedade nacional. Portanto, assim como na sociedade nacional, em virtude de diversos fatores históricos e culturais, a concepção de território vigente está condicionada a uma forma específica de organização econômica, política e cultural, apresentando por esse motivo características peculiares, a concepção de território Guarani possui suas particularidades e está diretamente relacionada ao modo de vida próprio à sua cultura.

Para os Guarani a terra possui sobretudo um valor simbólico. Ela não é vista tal qual na sociedade nacional, como uma propriedade privada, que como outra qualquer pode ser trocada por um equivalente geral e passar às mãos de várias pessoas, de acordo com os interesses e com o quantum de poder de compra que cada indivíduo possuir. ${ }^{5}$

$O$ termo da língua Guarani cujo significado mais se aproxima da concepção de "território" é "tekoa". 6 No entanto, o significado desse termo demonstra a "distância" existen- te entre a concepção de território para a sociedade nacional e a concepção de territorialidade para os Guarani. Isto porque um tekoa não é um espaço físico qualquer, ou seja, não é um simples território, mas, sim, um território com características específicas que possibilita aos Guarani realizar o seu "modo de ser". "O tekoa é traduzido como o lugar onde é possível realizar o modo de ser Guarani. Teko, 'o modo de ser', abrange a cultura, as normas, o comportamento, os costumes". (MONTOYA apud TOMMASINO, 1995, p.102)

Dentre essas características do tekoa, pode ser destacada a necessidade de que ele seja composto por uma parcela significativa de mata, que tenha água corrente, etc.

Um outro ponto importante sobre a territorialidade Guarani diz respeito à sua relativa mobilidade. Nesse sentido, LADEIRA (1990) destaca que, apesar de os Guarani fixarem suas aldeias em locais específicos e de constantemente se deslocarem para outros lugares, esses deslocamentos se dão de forma a tecer uma "malha" ou uma espécie de "rede" de relações sociais. Isto, em virtude dos laços de parentesco existentes entre membros de diferentes aldeias e subgrupos, que acabam gerando uma comunicação/circulação de pessoas entre as várias aldeias.

Além disso, esta autora destaca que, mesmo havendo uma sucessão de deslocamentos nos quais os ocupantes das aldeias se mudam para outros locais, existe também, em contrapartida, um movimento no sentido de reocupação dos antigos sítios.

Assim, conforme o raciocínio de Ladeira, embora os "limites" geográficos do território Guarani não estejam delineados conforme os sistemas de representação vigentes na sociedade nacional, tais como escrituras e outros elementos cartográficos, os deslocamentos dos Guarani sempre se dariam no interior de um mesmo espaço físico, cujos limites já teriam sido estabelecidos no interior de sua cultura em tempos imemoriais, e o seu território, antes de mais nada, significaria o "seu mundo".

"a despeito de sua 'invisibilidade', as migrações Mbya são uma constante que vêm se acentuando (...) As aldeias e os movimentos atuais vêm comprovar que, embora a disponibilidade de terras lhe seja irrisória e que cada vez mais seu espaço no seu próprio mundo esteja diminuindo, os Guarani continuam fiéis na identificação de seu território, elegendo seus lugares dentro dos mesmos limites geográficos observados pelos cronistas durante a conquista. (...) A terra, ou os lugares que procuram restringe-se, ainda hoje, nos mesmos 'limites' pré estabelecidos pelos àntepassados míticos." (LADEIRA, 1990, p.57-59)

No que diz respeito à circularidade presente na ocupação do território Guarani, tal como pode ser percebido na citação anterior, pode-se dizer que ela representa um elo comum entre os trabalhos de Ladeira e os de GARLET (1997).

Todavia, no que tange à questão dos limites do território Guarani, o mesmo não acontece. De forma contrária à de Ladeira, apoiado no estudo de fontes documentais e em história oral Garlet procura demonstrar que o território original Mbyá localizava-se numa região específica do Paraguai 
oriental, que era denominada como Yvy Mbyte (Centro da Terra) e que desde o final do século XIX os Mbyá tiveram que sair de seu território original em busca de novos locais, em virtude da ocupação de seu território por latifúndios caracterizados pela predominância de atividades extrativistas, principalmente de erva-mate e de madeira. Assim, segundo Garlet, com o passar do tempo a própria concepção de território Mbyá acabou sofrendo alterações.

Dessa forma, pode-se concluir que, apesar de existir uma vinculação entre o aspecto mítico de Yvy Marãey e os deslocamentos dos grupos Guarani, esses não podem ser explicados somente por esse aspecto. Ainda que tenham sido destacados somente alguns dos elementos da complexa cultura Guarani, deve ser esclarecido que a unidade entre esses elementos, ou seja, entre a religiosidade, o território e a mitologia específica de cada grupo confere a cada componente dos diversos subgrupos Guarani a sua identidade étnica; quer dizer, uma auto-identificação que se encontra muito mais relacionada com a cultura do grupo à qual ela pertence do que com a sua descendência étnica propriamente dita.

É nesse sentido que se pode considerar a identidade étnica de cada grupo ou mesmo subgrupo Guarani como um "modo de ser" específico, o que possibilita a utilização de expressões como "modo de ser Mbyá" ou "modo de ser Guarani”'

\section{A PRESENÇA GUARANI EM TERRI- TÓRIO QUE ATUALMENTE CONSTI- TUI O ESTADO DO PARANÁ}

De uma maneira bastante esquemática, pode-se dizer que, no período que se estende do século XVI ao século XX, o território que veio a constituir o Estado do Paraná presenciou alterações significativas quanto à predominância de diferentes populações pré-colombianas. Como será visto mais adiante e de forma mais aprofundada, em um primeiro momento predominaram os Guarani, em um segundo momento os Kaingáng e, posteriormente, houve uma reocupação Guarani. Porém, cabe destacar que, em todo esse período, a composição étnica não apenas neste estado mas também em outros desta região se caracterizou como multiétnica.

No século XVI, dentre outros grupos, destacavam-se os Carijó, ${ }^{7}$ os Cainguá (índios Guarani) e os Guayaná (índios Kaingáng) - que viviam, respectivamente, no litoral do Paraná, no Nordeste do Paraguai e no território que se estende do rio Paraná ao rio Iguaçu. ${ }^{8}$ (ANAÍ, 1983, p.19; ROSSATO, 1987, p.5)

Apesar do "silêncio oficial" sobre o assunto, 9 a colonização do Estado do Paraná constituiu-se um complexo processo histórico, traspassado não somente pela presença dessas populações e pela resistência que apresentaram em relação ao "branco", mas também por diferentes formas de inserção destes povos na chamada "sociedade nacional".

Os Carijó foram os primeiros povos pré-colombianos contactados pelo europeu neste território. NOELLI ([199-]), destaca que houve vários fatores que influencia- ram no seu desaparecimento, dentre os quais destacam-se a escravização e as epidemias.

"A ação contínua de escravização, aliada às guerras e, principalmente, às várias epidemias influíram para que houvesse uma nova configuração populacional do litoral paranaense, catarinense e rio-grandense a partir do século XVII. A população Carijó do litoral do Paraná e do norte de Santa Catarina foi destruída, com uma parte dos sobreviventes 'migrando' para o sul e outra parte, fugindo para o interior”. (NOELLI, ([199-]), p.8)

WACHOWICZ (1988) ressalta que os contatos dos portugueses e dos espanhóis com os Carijó eram caracteristicamente violentos, em virtude de que estes os associavam aos "Tupiniquins" de São Paulo, seus inimigos tradicionais. ${ }^{10}$ A violência desses contatos pode ser exemplificada pelo ataque e destruição da expedição enviada por Martim Afonso de Souza, em 1531, composta por oitenta homens, que objetivavam encontrar ouro no litoral; ou ainda, pela reação aos jesuítas em meados do século XVI: "Em 1562, alguns jesuítas aproveitando a companhia de espanhóis que partiram a pé de São Vicente até o Prata, chegaram ao território paranaense, com o objetivo de catequizá-los. Foram trucidados pelos carijó, pois foram considerados como espiões dos tupiniquim." (WACHOWICZ, 1988, p.12)

Entretanto, tal como NOELLI ([199-]) destaca, deve ser considerado também que, muitas vezes, as "violências" praticadas pelos grupos Carijó em relação aos europeus serviram como pretexto para a realização de investidas contra esses grupos, que tinham como objetivo obter força de trabalho escravo.

"É neste período, em 1585, desencadeada uma grande 'guerra justa' contra os Carijó, comandada por Jerônimo Leitão (Franco, 1954:204). A 'Guerra justa' podia ser desencadeada quando um grupo indígena atacasse os portugueses ou seus aliados nativos [os Tupinambá]. No período colonial, as 'guerras justas' foram pretexto para capturar e escravizar, burlando a legislação portuguesa estabelecida em 1570 , que assegurava a liberdade dos indígenas." (NOELLI, ([199-]), p.8)

Segundo WACHOWICZ (1988), em virtude do trabalho realizado pelos jesuítas junto a essas populações, os contatos posteriores dos portugueses com os Carijó foram bastante facilitados. Dessa forma os índios acabaram servindo à demanda de força de trabalho escravo para fazendas do litoral paulista, tendo sido explorados também em regiões auríferas do litoral paranaense e de outros estados.

As primeiras povoações européias fundadas no Paraná foram de origem espanhola. Em 1554 foi fundada a Vila de Ontiveros, localizada nas margens do rio Paraná, próxima à foz do rio Ivaí. Em 1556 esta povoação foi transferida para uma região próxima à foz do rio Piquiri e passou a ser denominada como Ciudad Real del Guairá. Em 1579, junto ao rio Ivaí, nas proximidades da foz do rio Corumbataí, foi fundada 
Vila Rica do Espírito Santo. Esta região constituiu a província de Vera ou Guairá, e o seu sistema de colonização se baseou nos adelantados e encomiendas.

Nesse sistema, eram designados para as colônias os adelantados (posto máximo da burocracia colonial durante os primeiros anos das colônias). Esses eram responsáveis em acompanhar a organização e a estruturação dessas colônias, e, após o término desse período, eram substituídos por um "vice-rei" ou "governador geral". Na ótica dos adelantados, a população indígena deveria ser "catequizada", "defendida" de seus inimigos e "iniciada em um ofício". Em contrapartida, deveriam pagar por esses "préstimos", seja através de valores monetários, seja através de prestação de serviços. Esse sistema era denominado encomiendas e, segundo Wachowicz, em pouco tempo se transformou num sistema de escravidão.

Pode ser percebido que havia posições distintas por parte dos espanhóis no que tange ao indígena que vivia no território que hoje constitui o Estado do Paraná, e que essas posições estavam diretamente relacionadas aos distintos objetivos envolvidos na questão.

Por um lado, havia os colonizadores que, como já destacado, exploravam essas populações e ainda objetivavam diminuir as penetrações portuguesas que preavam índios a oeste da linha de Tordesilhas e também contribuir para a obtenção de um porto marítimo junto ao oceano Atlântico, que pudesse vir a ser utilizado num futuro próximo.

Por outro, havia os jesuítas, que estavam interessados em conseguir um método de trabalho mais eficiente para a catequização dos índios, e que, com esse intuito, vieram a estabelecer povoações indígenas que foram denominadas reduções.

Segundo Wachowicz, as duas primeiras reduções foram fundadas em 1610 junto à margem esquerda do rio Paranapanema e receberam as denominações de Nossa Senhora de Loreto e de Santo Inácio Mini. Além dessas, foram fundadas outras onze, sempre próximas aos principais rios da então província do Guairá."

Apesar de determinados trabalhos indicarem cifras maiores, como o de WACHOWICZ (1988), por exemplo, que afirma ter existido mais de cem mil índios aldeados nas reduções, levantamentos mais precisos realizados até o presente momento, como o de MELIÀ (1993), limitam a população aldeada, naquela época, em aproximadamente $38 \mathrm{mil}$ pessoas.

Em 1628 uma expedição comandada por Raposo Tavares partiu para o Guairá, dentre outras de menor envergadura que também partiram para esta região. Segundo WACHOWICZ (1988), esta expedição destruiu todas as reduções jesuíticas existentes, com exceção das reduções Loreto e Santo Inácio Mini, que só não foram destruídas pelos paulistas porque os missionários fugiram do Guairá levando consigo a população aldeada. Cabe destacar que a expedição comandada por Raposo Tavares foi a maior de todas as expedições e que ela contou inclusive com a manipulação de tensões interétnicas para conseguir seus objetivos.

Em suas expedições os bandeirantes contavam com o apoio estratégico de um número considerável de indígenas provenientes de grupos inimigos dos Guarani, principalmente dos Tememinó. Esses foram atacados pelos bandei- rantes paulistas no início do século XVII e, a partir da década de 20 do mesmo século, passaram a instrumentalizar os ataques aos Guarani.

"Embora os inventários e testamentos do início do século XVII registrem uma ampla diversidade de grupos indígenas, a partir da segunda década esta cedeu lugar à predominância de cativos guarani nos plantéis paulistas. Isto sugere que os paulistas se ocuparam nos primeiros anos do século, em preparar o terreno para os assaltos de maior envergadura contra os Guarani, que caracterizaram o período 1610-40. Neste sentido, o aspecto mais importante das expedições contra os Tememinó residiu exatamente na ampliação dos quadros guerreiros dos paulistas, o que mais tarde viria a desempenhar papel de relevo nas investidas dos mesmos contra os Guarani que figuram nas crônicas do século XVI como habitantes da região entre São Paulo e Paraguai, sendo estes inimigos tradicionais de grupos guarani. Neste caso, seriam eles também os Tupi citados freqüentemente pelos jesuítas espanhóis como os fiéis ajudantes dos paulistas nos assaltos às missões. Manuel Preto, um dos principais líderes na destruição das missões de Guairá, supostamente comandava 999 arqueiros, sem dúvida uma referência aos guerreiros tememinó adquiridos em 1607." (MONTEIRO, 1994, p.62)

Cabe aqui destacar a necessidade de relativizar determinadas informações presentes na historiografia, principalmente no que diz respeito às populações indígenas. Um exemplo disso pode ser percebido na explicação dada por WACHOWICZ (1988) para os ataques realizados pelos bandeirantes paulistas às reduções.

Segundo este autor, o sucesso das reduções organizadas pelos espanhóis teria despertado os temores dos paulistas, que, dentre outros fatores, temiam uma expansão espanhola que pudesse chegar à baía de Paranaguá. Em suas próprias palavras: “A expansão das reduções espanholas, que já atingiam o médio vale do Tibagi, provocou o temor dos paulistas (...) Tomaram estes a firme deliberação de impedir esta expansão. Por este motivo, atacaram antes de serem atacados". (WACHOWICZ, 1988, p.32)

Assim, apesar de admitir a utilização de força de trabalho indígena como trabalho escravo desde o século XVI, como já discutido em parágrafos anteriores, no que diz respeito à motivação para a destruição das reduções do Guairá pelos bandeirantes paulistas esse elemento fica em segundo plano.

Segundo MONTEIRO (1994), a força de trabalho indígena durante os séculos XVI e XVII representou a principal base de apoio da economia paulista. Partindo de seu trabalho é possível perceber que historicamente os ataques ao território do Guairá estiveram diretamente relacionados à demanda de mão-de-obra escrava indígena, principalmente para o trabalho nas lavouras de trigo paulistas, e que, muito mais que defender o território do Guairá do avanço da colonização espanhola, os bandeirantes paulistas, em suas expe- 
dições, visavam aprisionar indígenas para atender à crescente demanda de força de trabalho escrava de São Paulo.

É preciso relativizar também a historiografia paulista, pois, como Monteiro destaca, ao contrário da historiografia convencional paulista, os indígenas que eram aprisionados não se destinavam a atender à necessidade de força de trabalho do litoral nordestino. Na verdade, o fluxo de cativos atendia à demanda do planalto paulista, abastecendo regiões onde a triticultura se desenvolvia e chegaria ao seu auge a partir da década de 30 , tais como os bairros rurais de Santana do Parnaíba, a oeste de São Paulo, de Cotia, que se localizava ao sul de Santana do Parnaíba, e a região do Juqueri, localizada ao norte de São Paulo e de Santana do Parnaíba.

\begin{abstract}
"Representando o auge do apresamento de cativos guarani, o surto bandeirante de 1628-41 relacionavase muito mais ao desenvolvimento da economia do planalto do que - como a maioria dos historiadores paulistas tem colocado - à demanda por escravos no litoral açucareiro. Sem dúvida, alguns - talvez muitos — cativos tomados pelos paulistas chegaram a ser vendidos em outras capitanias. Mas este comércio restrito não explica nem a lógica nem a escala do empreendimento bandeirante. (...) A versão convencional da historiografia brasileira sustenta que as grandes expedições contra as reduções coincidiram com uma crise aguda de mão-de-obra no Nordeste açucareiro, decorrente das invasões holandesas e da interrupção no tráfico de escravos africanos, em consequiência da perda de Angola. Porém, este argumento é deficiente no seu recorte cronológico, pois a expedição de Raposo Tavares saiu alguns anos antes da invasão de Pernambuco e é bem anterior à tomada de Luanda." (MONTEIRO, 1994, p.77)
\end{abstract}

Com o desmantelamento das reduções jesuíticas do Paraná, os bandeirantes paulistas passaram a buscar cativos Guarani em regiões mais ao sul do Guairá, nas missões provenientes do Tape e do Uruguai, onde encontraram muitas dificuldades, sobretudo a resistência oferecida pelos Guarani das missões de Jesus Maria, Cristóbal, Santa Ana e São Joaquim, que se reuniram na missão de Natividad.

Neste período pode ser observada uma expansão de populações Kaingáng sobre os outrora territórios Guarani. A partir de então, os Kaingáng passaram a predominar numericamente sobre as demais populações pré-colombianas. Todavia, deve ser levado em consideração que a destruição das reduções não implicou, necessariamente, um completo esvaziamento da presença Guarani em território paranaense. Nesse sentido, Tommasino destaca que

\footnotetext{
"Mesmo depois da destruição das reduções, é possível que muitos grupos tenham se dispersado pela região, voltando à vida livre nas florestas. A maioria dos índios foi levada como mão de obra escrava, outros fugiram para o sul do país onde os jesuítas fundaram novas reduções e uma minoria certamente permaneceu, apeșar da afirmação de Wachowicz de que a região voltou a ficar abandonada. Nossa interpreta-
}

ção é que os índios (Guarani e Jê) retornaram à vida livre, com predominância da expansão Kaingang que, fugindo das frentes de ocupação luso-brasileira do leste para o oeste, foram empurrados para o interior, isto é, em direção ao rio Paraná e depois, para o Sul. Embora os historiadores (...) costumem afirmar que após a destruição das reduções do Paraná toda a região teria permanecido abandonada por mais de um século, o que se observa é que outros grupos Guarani e demais etnias que não estavam reduzidas puderam se expandir sem serem molestadas pelos bandeirantes paulistas, que passaram a prear índios em outras províncias." (TOMMASINO, 1995, p.51 e 73)

A utilização de populações indígenas para a conquista dos objetivos dos colonizadores não se restringiu aos Tememinó e, muito menos, à destruição das reduções no início do século XVII. Quando se analisa a colonização do Estado do Paraná, percebe-se que esta envolveu uma complexa trama de relações sociais entre colonizadores e determinadas populações indígenas, que acabou instrumentalizando em grande parte esse processo.

Nesse sentido, cabe ressaltar, dentre outras práticas, o estabelecimento de alianças que foram firmadas com alguns grupos Kaingáng desde o início do século XIX, como a aliança com os Camés e a aliança com o cacique Manoel Arapquimbe, que possibilitaram a ocupação dos campos de Guarapuava e de Palmas, respectivamente. Estes grupos lutaram contra os grupos Kaingáng que não aceitavam a presença "branca" em suas terras como, por exemplo, os Dorins e os Kaingáng liderados pelo cacique Joty.

Além dessas alianças, que praticamente dividiam as populações indígenas, colaborando significativamente para o seu enfraquecimento, houve também a promoção, por parte do estado, de migrações de populações provenientes da então província de Mato Grosso para o Paraná, visando atender determinados "objetivos do Império".

Com vistas em obter uma comunicação entre a província do Mato Grosso e o litoral, João da Silva Machado, futuro Barão de Antonina - então senador do Império com o apoio imperial, buscou estabelecer uma ligação fluvial através dos rios Tibagi e Paranapanema com essa província.

Dentro desse contexto, e através do estabelecimento de alianças, como a firmada com o cacique Kayová Liguajurú de Mato Grosso, entre 1852 e 1854, foram trazidas dessa província populações Kayová, que eram consideradas "pacíficas", para serem aldeadas nas proximidades do caminho fluvial. Esses grupos foram trazidos com o intuito de servir como pontos de apoio para quem viesse a utilizar esse caminho e também com o intuito de salvaguardá-los de possíveis ataques de índios "bravios", e contribuíram para a "pacificação" dos Kaingáng da bacia do rio Tibagi.

"Inicialmente, no trajeto Tibagi-Paranapanema em direção ao rio Paraná, não existiam toldos indígenas. Em consequiência, dificuldades haveriam de surgir para as pessoas que utilizassem o referido caminho. Esses viajantes não teriam pontos de apoio para a 
navegação. (...) A fim de sanar essa deficiência, ordenou João da Silva Machado que os seus sertanistas fossem buscar, nas margens do Ivinheima e Iguatemú, os índios caiuá. [Em 1852] (...) a mando do Barão de Antonina, saiu uma expedição ao Ivinheima, para trazer o maior número possível de caiuá, para aldearemse no Tibagi. Vieram cerca de 171 no todo; Desde o início da planificação da navegação do TibagiParanapanema em direção à província de Mato Grosso foi prevista a fundação, na outra margem do Tibagi (margem esquerda) em frente à colônia do Jataí, de um aldeamento indígena, inicialmente conhecido como colônia D. Pedro, depois aldeamento D. Pedro e finalmente aldeamento S. Pedro de Alcântara (...) Destinava-se (...) a agrupar os índios caiuá que haviam vindo da Província de Mato Grosso. No início de 1854, o barão de Antonina calculava seu número em 200 pessoas, e esperava para breve a incorporação de mais 40." (idem, p.15-16; 20 e 17)

$\mathrm{Na}$ periodização inicialmente proposta ${ }^{12}$ sobre alterações na composição étnica da população indígena presente no atual território paranaense, as migrações de populações Guarani patrocinadas pelo estado, a partir da segunda metade do século XIX, podem ser consideradas como um ponto de referência de um processo de reocupação do estado por populações desta etnia.

Todavia, deve ser ressaltado que os deslocamentos Guarani que deram origem a fixações no Estado do Paraná, assim como em outros estados das regiões sul e sudeste brasileiras, não se resumem às migrações patrocinadas pelo estado durante a década de 50 do século passado.

Segundo Tommasino, no período que compreende 1820 e 1912 houve várias migrações de povos Guarani procedentes do Paraguai e do Mato Grosso, que, ao buscarem atingir o leste do continente, acabaram possibilitando essas fixações. "O assentamento forçado ou espontâneo desses grupos e seus descendentes pelos vários Estados - do Rio Grande do Sul ao Espírito Santo - são resultados dessas migrações e das políticas indigenistas do Império, e posteriormente, da República." (idem, 1995, p.97)

Em suma, pode-se dizer que os dados apresentados até o momento permitem observar que houve a realização de alianças entre colonizadores e determinados caciques visando, muitas vezes, a proteção e a utilização de conhecimentos sobre as terras que se queria conhecer e ocupar; e que houve também a manipulação de tensões interétnicas que acabaram contribuindo para o complexo processo de colonização do estado.

\section{As populações Guarani ałualmente pre- sentes no Estado do Paraná e suas origens}

Atualmente, a população indígena do Estado do Paraná está estimada em aproximadamente 9 mil pessoas das etnias Kaingáng e Guarani. Destes, a maior parte encontra-se aldeada junto a dezoito áreas indígenas (AIs), conforme pode ser visto no quadro a seguir.

\begin{tabular}{|c|c|c|c|}
\hline № & AIs & Município & Etnias \\
\hline 1 & Laranjinha & Santa Amélia & $\begin{array}{l}\text { Guarani } \\
\text { (Kayová e Ñandéva) }\end{array}$ \\
\hline 2 & Pinhalzinho & Tomazina & $\begin{array}{c}\text { Guarani } \\
\text { (Kayová e Ñandéva) })^{(1)}\end{array}$ \\
\hline 3 & $\begin{array}{l}\text { Barão de } \\
\text { Antonina }\end{array}$ & $\begin{array}{l}\text { São Jerônimo } \\
\text { da Serra }\end{array}$ & $\begin{array}{c}\text { Guarani } \\
\text { (Ñandéva)/Kaingáng }\end{array}$ \\
\hline 4 & Apucarana & Londrina & Kaingáng \\
\hline 5 & $\begin{array}{l}\text { São Jerônimo } \\
\text { da Serra }\end{array}$ & $\begin{array}{l}\text { São Jerônimo } \\
\text { da Serra }\end{array}$ & $\begin{array}{c}\text { Guarani } \\
\text { (Ñandéva)/Kaingáng }\end{array}$ \\
\hline 6 & Mococa & Ortigueira & Kaingáng ${ }^{(2)}$ \\
\hline 7 & Queimadas & Ortigueira & Kaingáng \\
\hline 8 & Ivaí & Pitanga & $\begin{array}{c}\text { Guarani } \\
\text { (Ñandéva) e Kaingáng } \\
\left({ }^{(3)}\right.\end{array}$ \\
\hline 9 & Faxinal & $\begin{array}{l}\text { Cândido de } \\
\text { Abreu }\end{array}$ & $\begin{array}{c}\text { Guarani } \\
\text { (Ñandéva) e Kaingáng }\end{array}$ \\
\hline 10 & Tekoa-Añetete & $\begin{array}{l}\text { Diamante } \\
\text { do Oeste }\end{array}$ & $\begin{array}{c}\text { Guarani } \\
\text { (Ñandéva) }\end{array}$ \\
\hline 11 & Marrecas & $\begin{array}{l}\text { Guarapuava } \\
\text { Turvo } \\
\text { Prudentópolis }\end{array}$ & Kaingáng \\
\hline 12 & Ocoí & $\begin{array}{l}\text { São Miguel } \\
\text { do Iguaçu }\end{array}$ & $\begin{array}{l}\text { Guarani } \\
\text { (Ñandéva) }\end{array}$ \\
\hline 13 & Ilha da Cotinga & Paranaguá & Guarani (Mbyá) $^{(4)}$ \\
\hline 14 & Rio das Cobras & $\begin{array}{l}\text { Laranjeiras do Sul } \\
\text { Quedas do Iguaçu }\end{array}$ & $\begin{array}{l}\text { Guarani (Mbyá) e } \\
\text { Kaingáng }\end{array}$ \\
\hline 15 & Rio Areia I e II & Inácio Martins & Guarani (Mbyá) \\
\hline 16 & Rio Areia & Inácio Martins & Guarani (Ñandéva) ${ }^{(5)}$ \\
\hline 17 & Mangueirinha & Mangueirinha & $\begin{array}{l}\text { Guarani (Mbyá) e } \\
\text { Kaingáng(6) }\end{array}$ \\
\hline 18 & Palmas & $\begin{array}{c}\text { Palmas (Pr) } \\
\text { Abelardo Luz (SC) }\end{array}$ & Kaingáng \\
\hline \multicolumn{4}{|c|}{$\begin{array}{l}\text { (1) Fonte: ROSSATO (1987). Obs.: a última edição do Instituto Sócio-Ambiental não faz } \\
\text { menção aos Kayová desta AI. }\end{array}$} \\
\hline \multicolumn{4}{|c|}{$\begin{array}{l}\text { (2) Fonte: informação verbal dada pela administração regional da FUNAI de Guarapuava } \\
\text { à pesquisadora Kimiye Tommasino em } 1997 \text {. }\end{array}$} \\
\hline \multicolumn{4}{|c|}{$\begin{array}{l}\text { (3) Fonte: FUNAI (1997, p.19). Indica apenas a presença Kaingáng, porém, segundo } \\
\text { publicação do Instituto Sócio-Ambiental, esta AI também seria habitada por um grupo } \\
\text { Guarani-Ñandéva. Trata-se de um dado novo, a ser esclarecido. }\end{array}$} \\
\hline \multicolumn{4}{|c|}{${ }^{(4)}$ Fonte: LADEIRA (1992, p.147). } \\
\hline \multicolumn{4}{|c|}{$\begin{array}{l}\text { (5) Fonte: informação verbal fornecida pelo Sr. Edívio Battistelli, da Assessoria para } \\
\text { Assuntos Indígenas-Curitiba, em 16.6.97, à pesquisadora Kimiye Tommasino. }\end{array}$} \\
\hline
\end{tabular}

Conforme pode ser constatado no quadro, não existe uma divisão totalmente rígida no que diz respeito à composição étnica nas áreas indígenas do estado.

Como visto anteriormente, os Guarani são lingüisticamente e culturalmente divididos em três subgrupos ou parcialidades: Kayová, Mbyá e Ñandéva.

Com base nas informações obtidas até o presente momento, serão discutidas, a seguir, as origens das populações Guarani atualmente presentes no Estado do Paraná. Para facilitar a exposição, serão utilizados tópicos nos quais serão agrupadas as informações sobre as populações das áreas indígenas, de acordo com suas parcialidades.

Todavia, cabe ressaltar o fato de que grande parte dos estudos realizados sobre os grupos Guarani presentes no Paraná não faz sequer menção à sua cosmologia, o que acaba por dificultar uma visão mais aprofundada sobre os grupos desta etnia. Este trabalho não tem como objetivo realizar essa 
tarefa, mas deve salientar a necessidade de que, em trabalhos futuros, haja a preocupação de combinar a experiência histórica desses grupos à sua cosmologia. Além disso, é importante frisar que existe uma considerável carência de informações sobre as populações Guarani presentes no Paraná. Das três parcialidades desta etnia, esta carência se manifesta principalmente em relação aos Kayová e aos Ñandéva. Entretanto, mesmo no caso dos Mbyá, não existem informações sobre todos os grupos presentes.

\section{Os Guarani Kayová (Als Laranjinha e Pinhalzinho)}

Conforme já mencionado, existem registros de migrações de populações Kayová, ocorridas desde 1852, que se dirigiram para o Estado do Paraná, migrações essas patrocinadas pelo governo imperial. Existem documentos históricos que comprovam esses deslocamentos como, por exemplo, o relato de Elliot - um dos sertanistas empregados pelo Barão de Antonina --, datado de 1898, no qual são descritas, em minúcias, a viagem até a então província de Mato Grosso, os contatos com os Kayová e as dificuldades enfrentadas para trazê-los ao Paraná.

Todavia, não basta simplesmente recuperar esta informação histórica, dizendo que parte significativa dos Kayová presentes em território paranaense durante o século passado provinham dessas migrações patrocinadas pelo estado no início da década de 50. É necessário procurar compreender a conjuntura histórico-cultural em que esses grupos se encontravam para que se possa apreender o significado que essas populações atribuíam à realização desses deslocamentos. Nesse sentido, as observações de TOMMASINO (1995) mostram-se bastante pertinentes.

Segundo esta pesquisadora, deve ser levado em consideração que, em virtude das dificuldades pelas quais as populações Kayová contactadas no Mato Grosso sc encontravam, sobretudo no que diz respeito às rivalidades existentes em relação a populações de outras etnias, como também em virtude de fatores oriundos de sua própria cosmologia e da forma como os sertanistas propuseram a ida às terras paranaenses, esses deslocamentos teriam adquirido um sentido mítico para os Kayová. (TOMMASINO,1995, p.100-102)

Tommasino destaca o fato de que determinados trechos do relato de Elliot demonstram a "proximidade" ou "semelhança" da proposta dos colonizadores no que diz respeito às características do local para onde os índios seriam conduzidos e à forma como seriam "protegidos" com aquelas relacionadas pelos Guarani à Yvy Marãey (Terra sem Mal), conferindo, assim, uma interpretação religiosa Guarani a essas migrações. Em suas próprias palavras:

"O convencimento dos Kayoá foi eficaz por duas razões: de um lado, porque Lopes prometeu-lhes que teriam toda a proteção de seu patrão e nada lhes faltaria em alimentação e segurança. De outro, porque os Kayoá estavam sendo acossados pelos muitos inimigos e desejavam mudar para local mais seguro. (...) o Tibagi foi interpretado como a Terra sem Mal (Ivy
Marãey) que procuravam ou ao menos uma terra com as características ideais para desenvolverem seu 'modo de ser' (teko) num tekoa (...) A migração, então, teria deixado de ser apenas uma transferência de localidade e transmutara-se em movimento religioso. (...) Entre 1820 e 1912, vários grupos Guarani saíram do Mato Grosso e Paraguai em busca do Yvy Marãey. Havia, portanto, nesse período, condições histórico-culturais que favoreciam a constituição de movimentos de natureza religiosa entre os Guarani." (idem, p.97, 100 e 102)

Além disto, deve ser levado em conta que provavelmente houve migrações de grupos Kayová anteriores às "patrocinadas" pelo Estado do Paraná, como a ocorrida em 1830, descrita por ELLIOT (1856).

Segundo WACHOWICZ (1988), no final do século passado os aldeamentos de São Pedro de Alcântara e de São Jerônimo abrigavam um número significativo de pessoas da etnia Guarani Kayová. Todavia, deve ser considerada, também, a existência de populações Kayová dispersas no Paraná, algumas vezes, nas proximidades dos aldeamentos, como o grupo liderado pelo cacique Caripi, descrito por BOUTIN (1979, p.70), que em 1870 habitava nas proximidades do aldeamento de São Jerônimo, próximo a um grupo Kaingáng - o que atesta o fato de que, em determinados momentos, houve a convivência de grupos dessas duas etnias em áreas contíguas. "Em 1870 já havia no aldeamento de São Jerônimo, índios coroado convivendo com cayoá, (...) O cacique caiuá, chamado Caripi, e o cacique coroado, chamado Carneiro, residiam fora do aldeamento à margem do rio Tibagi e se dedicavam à lavoura de cana-de-açúcar". (BOUTIN, 1979, p.70)

WACHOWICZ (1988) destaca que, devido à ocorrência de uma epidemia de varíola em 1877 , que atingiu a população desses aldeamentos, morreram em apenas uma semana aproximadamente 400 índios Kayová.

TOMMASINO (1995), por sua vez, ressalta que, em virtude dessa epidemia e também da extinção dos aldeamentos de Pirapó e de Santo Inácio do Paranapanema (ocorridas, respectivamente, em 1862 e 1878), houve uma dispersão dos Guarani que habitavam essas áreas - tanto dos Kayová como dos Ñandéva. Assim, em virtude das epidemias e da dispersão Kayová essa parcialidade acabou se tornando minoritária no estado.

Como será visto mais detalhadamente no tópico sobre os Ñandéva - a outra parcialidade Guarani presente nas áreas indígenas Laranjinha e Pinhalzinho - , com a criação desses dois postos indígenas, na década de 30 do presente século, alguns dos grupos Kayová e Ñandéva que estavam dispersos pela região acabaram se aldeando nesses postos.

\section{Os Guarani Mbyá (Als Cotinga, Mangueiri- nha, Rio das Cobras e Rio Areia I e II)}

Conforme já destacado anteriormente, existem poucas informações sobre os Mbyá. Sobre esses grupos há o trabalho de PIRES (1975), o de LOMBARDI \& NAKAMURA (1981) e os trabalhos de LADEIRA (1990; 1992). Enquanto 
os trabalhos de Ladeira têm como enfoque os grupos Mbyá do litoral, não se limitando às populações presentes no Estado do Paraná, tanto os trabalhos de Pires como o de Lombardi \& Nakamura se referem aos Mbyá de Mangueirinha, que convivem nesta AI com índios Kaingáng. Sobre os Mbyá de Rio das Cobras e Rio Areia I e II não há qualquer informação.

O trabalho de PIRES (1975) tem como objetivo analisar as relações intertribais da população da Área Indígena Mangueirinha (relações entre os Guarani Mbyá e os Kaingáng). Nesse sentido, sua importância deve ser destacada, em virtude de que se trata de um trabalho pioneiro sobre o assunto, tendo sido escrito em um período em que havia muito poucas reflexões sobre relações intertribais. Já o trabalho de LOMBARDI \& NAKAMURA (1981) procura, simplesmente, analisar a inserção da produção agrícola da população de Mangueirinha na estrutura agrícola do estado.

Entretanto, cabe ressaltar que em ambos os trabalhos há limitações significativas, à medida que os seus autores exploram principalmente os aspectos sociológicos como, por exemplo, as diferentes relações de dominação que se estabelecem em relação ao grupo analisado, sem se aprofundarem nos aspectos relacionados à sua cultura.

Já os trabalhos de LADEIRA (1990; 1992) possuem, dentre outros méritos, o de proporcionar ao leitor um mapeamento dos grupos Mbyá atualmente presentes no litoral dos estados do Paraná e São Paulo. Porém, ao centrar sua análise na cosmologia do subgrupo Mbyá do litoral, correlacionando-a à questão da terra, a autora não traz informações sobre os demais grupos Mbyá existentes no Estado do Paraná, o que dificulta a composição de um quadro sobre os Mbyá deste estado que articule, de maneira satisfatória, sua cosmologia com as informações históricas.

Uma vez indicadas, em linhas gerais, a abrangência e as limitações de cada trabalho, procurar-se-á, a partir deste momento, apresentar as informações de que se dispõe sobre os Guarani Mbyá.

Segundo LADEIRA (1990), o primeiro povoado estabelecido no Paraná foi o de Nossa Senhora das Mercês de Cotinga, formado essencialmente por degredados e náufragos das expedições do período compreendido entre 1501 e 1504. Com o auxílio de índios que guiaram suas embarcações, estes teriam chegado à ilha e nela permanecido por aproximadamente vinte anos, período no qual teriam conquistado a confiança dos Carijó e ocupado o continente.

Os grupos Guarani Mbyá aldeados no litoral do Paraná encontram-se presentes nas ilhas da Cotinga, do $\mathrm{Mel}$ (município de Paranaguá), das Peças e do Superagui (município de Guaraqueçaba).

Em seu trabalho mais recente, LADEIRA (1996) apresenta um mapeamento mais completo sobre os Mbyá do litoral, que abrange inclusive o litoral do Estado de São Paulo. Através deste podem ser identificadas as aldeias Mbyá do litoral paranaense, que são: Aldeia Jacutinga, Aldeia da Pescada, Aldeia das Peças, Aldeia do Superagui, Aldeia da Barra do Ararapira e Aldeia Cerco Grande.

Como já destacado anteriormente, Ladeira considera os grupos Mbyá do litoral como portadores de algumas especificidades que os distinguiriam dos demais Mbyá. Isto principalmente no que diz respeito à perseverança com a qual enfrentam as dificuldades para cumprir o seu ideal religioso, ou seja, a migração para a região próxima à Serra do Mar, por eles considerada como o ponto de passagem para Yvy Marãey.

"Nimuendajú (1987) já observara a perseverança dos Guarani, apontada em seus relatos sobre as caminhadas em direção ao mar, que presenciou no início do século. Hoje também se comprova a insistência dos Mbya em permanecer no litoral, muitas vezes em locais desfavoráveis e inadequados a eles, do ponto de vista da subsistência, e sem recursos". (LADEIRA, 1990, p.28)

Esta autora destaca que os deslocamentos dessas populações no sentido leste, ao contrário do que possa parecer à primeira vista, não se devem pura e simplesmente a razões históricas que poderiam tê-los motivado, mas que, na verdade, já se constituíam práticas comuns durante o período que antecedeu a chegada dos europeus ao continente americano.

Como pode ser compreendido nos trabalhos desta autora, a mobilidade Mbyá, assim como a comunicabilidade existente entre as diversas aldeias Mbyá, acabam por dificultar a realização de um "mapeamento" dessas populações no que tange à determinação de suas origens e fixação. Isto em virtude de que não se trata simplesmente de uma população que se teria deslocado de um local a outro em um período específico, mas, sim, de um padrão de ocupação que está diretamente relacionado às especificidades culturais do grupo, dentre as quais, sobretudo, uma concepção particular de territorialidade, como já visto anteriormente. O levantamento desses dados também se torna uma tarefa difícil em virtude da carência de registros presentes na historiografia paranaense sobre os Guarani do litoral e, também, de sua imprecisão no que diz respeito às divisões étnicas.

"Se, até os anos sessenta, como é o caso dos trabalhos citados, encontram-se alguns registros e documentos sobre a presença Guarani no litoral sul de São Paulo, o mesmo não sucede com relação às aldeias contemporâneas do litoral norte de São Paulo, e dos litorais do Rio de Janeiro, Paraná e Santa Catarina. (...) Se hoje é possível distinguir a ocupação e o território, coincidente ou não, dos diferentes subgrupos Guarani da América, o mesmo não se sucedia com relação ao território original delineado pelos cronistas e historiadores. Algumas tentativas de classificação dos grupos que habitavam a região foram feitas, mas, em geral, várias etnias eram agrupadas como sendo uma só nação e é possível que as disparidades de informações devam-se, além de razões históricas, também à complexidade e à natureza da ocupação das diversas etnias que viviam nas vastas matas inexploradas do continente sul-americano, ao contrário do que acontece hoje. (...) Essas indefinições perduraram durante séculos, o que dificulta pesquisas sobre o assunto." (idem, p.50 e 48).

Assim, segundo a autora, para compreender as origens dos grupos Mbyá do litoral é necessário adicionar às 
poucas informações históricas confiáveis informações provenientes de sua cosmologia.

Na cosmologia Mbyá, o seu território é muito bem delimitado, sendo constituído por uma extensão de terra que teria o seu começo na Argentina, no Uruguai e no Paraguai e o seu final (yvy apy) - final do mundo - no litoral sul brasileiro. Nas narrativas míticas são encontradas descrições sobre a ocupação de determinados pontos do Paraná e principalmente no que diz respeito à ocupação das ilhas do litoral:

"Quando eles vieram, eles passaram onde hoje se chama Argentina, Uruguai, Paraguai. Depois vieram para esse mundo (Brasil). Então vieram para este meio do mundo (yvymbytere). Então começou a caminhada para a beira do oceano. E foram fundando vários lugares para depois 'serem cidades' (tentã). Passaram em Curyty (Curitiba) e pararam algum tempo. Ali se separaram. Alguns desceram pelo mato, em direção ao mar, a procura de seu lugar. E encontraram Opavãpy ou Iparavãpy (Paranaguá). E, de novo, se separaram naquele lugar. E de lá foram para as ilhas (...) no meio do oceano. (...) Alguns foram para Jacutinha (Ilha da Cotinga), alguns foram para Iretã (Ilha do $\mathrm{Mel}$ ), algumas famílias foram para Piragui (Superagui), para todas as ilhas". (idem, p.50-51)

Além disso, Ladeira ressalta também os deslocamentos, testemunhados por Schaden, de populações Mbyá provenientes do leste paraguaio e do nordeste argentino que teriam passado pelo Rio Grande do Sul, Santa Catarina e Paraná, tendo como objetivo o litoral paulista.

"há o testemunho de SCHADEN sobre as levas de Mbyá originárias do leste paraguaio e nordeste argentino rumo ao litoral de São Paulo, passando pelo Rio Grande do Sul, Santa Catarina e Paraná. Schaden menciona a chegada de três grupos: em 1924, 1934 e 1946." (idem, p.50)

Assim, pode-se dizer que a população Mbyá que atualmente habita o litoral paranaense é composta por pessoas que teriam migrado da Argentina e do Paraguai para o litoral das regiões sul e sudeste brasileiras, e que, segundo Ladeira, estariam buscando reocupar territórios que já eram seus em tempos imemoriais. ${ }^{14}$

Apesar das singularidades do trabalho de LOMBARDI \& NAKAMURA (1981), e do trabalho de PIRES (1975), destacadas acima, as informações que trazem sobre os Mbyá de Mangueirinha, em certa medida, são convergentes e complementares.

Segundo LOMBARDI \& NAKAMURA (1981), os Guarani de Mangueirinha são oriundos do Rio Grande do Sul e teriam se deslocado para a região, a partir do século XVII, em virtude, além de outros motivos, de as frentes de expansão colonialista estarem alcançando o seu território.

"Dos Guarani, poucas são as informações obtidas e isto não nos permite fazer amplas generalizações his- tóricas. De acordo com os relatos verbais, a comunidade Guarani, que habitava a Reserva de Mangueirinha, se deslocou desde o extremo sudeste do atual Estado do Rio Grande do Sul, fugindo das investidas promovidas pelas frentes de expansão colonialista, desde meados do século XVII. Migrando sucessivamente, chegaram à região habitada pelos Kaingang, havendo diversas guerras entre os dois grupos tribais, que debilitados pelas guerras inter-tribais, pela luta contra o avanço colonialista e começando a sofrer as consequências da desestruturação tribal provocada pelo contato com os brancos, aceitaram viver num território comum, embora em regiões distintas." (LOMBARDI e NAKAMURA, 1981, p.53)

Todavia deve ser ressaltado que o trabalho desses autores é passível de vários questionamentos, que não se limitam ao enfoque por eles adotado, mas se estendem, também, sobre a confiabilidade de algumas das informações que fornecem. Como pode ser visto no trecho acima citado, os autores fazem afirmações sobre um período de tempo muito amplo (três séculos) baseando-se apenas em relatos verbais. Caberia perguntar: será que a memória dos entrevistados poderia ir tão longe? Sem dúvida, há a necessidade de realizar um estudo mais rigoroso, baseado não somente em relatos verbais, mas também em documentos históricos (relatórios de província, cartas, etc.) para que se possa ter informações mais seguras a esse respeito.

Ainda segundo Lombardi \& Nakamura, os Guarani tiveram que disputar um "espaço" no território ocupado por populações Kaingáng originárias da região da mata atlânti$\mathrm{ca}$, as quais, em virtude das entradas e bandeiras, se deslocaram num primeiro momento no sentido oeste, chegando até a Serra da Esperança (sul do atual Estado do Paraná), e posteriormente, em virtude de novas investidas e também da expansão colonizadora, se dividiram em dois grupos. Um gruo fixou-se no local onde posteriormente se situaria o Posto Indígena Guarapuava e o outro deslocou-se no sentido sudoeste até as margens do rio Iguaçu, local do atual Posto de Mangueirinha.

"Os índios Kaingang, que atualmente habitam nos Postos Indígenas de Guarapuava e Mangueirinha, no início das 'entradas e bandeiras' habitavam a extensão da mata atlântica, localizada onde hoje se situa a cidade de Curitiba. (...) foram acuados desde o século XVII rumo ao oeste (...) Acabaram se localizando nas matas de araucária na Serra da Esperança (local onde hoje se situa o Posto Indígena Guarapuava). (...) Com o início da expansão colonizadora, provocada pela frente agro-pastoril, ocorreu a cisão do grupo em dois novos bandos: o de Guarapuava, que permaneceu [e ainda permanece] na região (...) o outro, se deslocou rumo sudoeste, até encontrar o Rio Iguassú, onde se fixou e cujo território tribal compreendia as matas localizadas desde o Rio Lageado Grande até o Mangueirinha, no início do século XIX. (...) Os índios, que tinham resistido até este final do século XIX, se viram cercados pelas diversas frentes de expansão 
e ocupação e acabaram por ser contatados e utilizados na abertura de picadas e linhas de demarcação das fronteiras (...) muitos deles foram utilizados como batedores, guias e mão-de-obra para a abertura de estradas e carregamento dos apetrechos militares do Batalhão sediado em 'Chopim' e optaram, mediados pelo cacique Antonio Joaquim Cretã, em receber, pelos trabalhos prestados, as terras que já habitavam, o que thes foi concedido pelo Imperador D. Pedro II e que foram legitimadas pelo Governo do Estado do Paraná em 1903”. (LOMBARDI \& NAKAMURA. p.50-52)

PIRES (1975) destaca que os Guarani que atualmente habitam uma parte do posto Mangueirinha denominada "Palmeirinha" são provenientes de dois grupos. O primeiro, comandado pelo "capitão" Gervásio, teria chegado há aproximadamente sessenta anos, ${ }^{15}$ vindo do Rio Grande do Sul, rumo a São Paulo. O segundo, liderado pelo "capitão" Americano, teria se instalado junto a um arroio denominado Butiá. Todavia, como a autora salienta, não existem maiores informações que possam indicar o período no qual os Mbyá teriam se estabelecido nesse arroio. Em suas próprias palavras:

'Além desse grupo comandado pelo 'capitão' Gervásio, chegou outro, posteriormente, comandado pelo 'capitão' Americano, que foi morar em Butiá, um arroio que passa dentro das terras da reserva. Sobre esse grupo foi impossível obter maiores informações, já que não resta ninguém lá. Mas, até hoje, o Butiá é apontado pelos Guarani como divisa entre a sua área e a dos Kaingang". (PIRES, 1975, p.191-192)

\section{Os Guarani Ñandéva (Als Laranjinha, Pinhal- zinho, São Jerônimo, Barão de Antonina, Ivaí, Faxinal, Avá-Guarani, Rio Areia e Tekoa-Añe- tete)}

Antes de discorrer sobre os Ñandéva, é necessário ressaltar que, assim como ocorre com os demais subgrupos Guarani (Kayová e Mbyá), a denominação “Ñandéva” é utilizada para agrupar lingüisticamente vários grupos que, muitas vezes, possuem características dialetais próprias. Nas palavras de DOOLEY (1991, p.5): "Como era também o caso com Kaiwá (...) e Mbyá, Ñandéva era originalmente um termo que abrangia vários grupos distintos, cada um falando um dialeto (ou subdialeto) um tanto diferente dos outros."

É necessário destacar, também, a existência de autodenominações através das quais os componentes de cada grupo se contrapõem aos dos demais. Isso permite compreender a existência de diferentes nomenclaturas para grupos Nandéva.

NIMUENDAJÚ (1987) destaca que, desde o começo do século XIX, houve migrações de vários grupos Ñandéva que, partindo do Mato Grosso e do Paraguai, buscavam atingir a Terra sem Mal. Em seu trabalho, ele destaca os Tañyguá, os Oguauiva e os Apapocúva.
"No princípio do século XIX começou entre as tribos Guarani daquela região um movimento religioso que até hoje ainda não está completamente extinto. Pajés, inspirados por visões e sonhos, constituíramse em profetas do fim iminente do mundo; juntaram à sua volta adeptos em maior ou menor número, $\mathrm{e}$ partiram em meio a danças rituais e cantos mágicos, em busca da 'Terra sem Mal'; alguns a julgavam situada, conforme a tradição, no centro da terra, mas a maioria a punha no leste, além do mar. Somente deste modo esperavam poder escapar à perdição ameaçadora." (NIMUENDAJÚ, 1987, p.8-9)

Através dessas migrações, essas populações esperavam chegar até a zona litorânea, localizada a leste do continente atlântico. No entanto, vários fatores acabaram dificultando seu objetivo, dentre os quais podem ser destacados: perseguições, tentativas de escravização, intervenções de autoridades da sociedade nacional e epidemias que acabaram dizimando, em alguns casos, quase a totalidade das pessoas que compunham esses grupos.

O trabalho de Nimuendajú permite compreender que durante o final do século XVIII e início do século XIX houve uma intensa movimentação de grupos Guarani Ñandéva provenientes do Mato Grosso e do Paraguai, que, ao se deslocar para o leste visando atingir a Terra sem Mal, acabaram atingindo localidades paulistas, tendo sido, na maior parte das vezes, e por diversos motivos, impedidos de alcançar seu objetivo.

Alguns grupos conseguiram chegar ao litoral sudeste do país, mas a grande maioria acabou sendo fixada - em alguns casos espontaneamente, em outros, de forma praticamente compulsória - no posto indígena paulista de Araribá.

Como já ressaltado anteriormente no tópico sobre os Kayová, em virtude da ocorrência de epidemias de varíola, em meados do século XIX, que atingiram os aldeamentos de Pirapó e de Santo Inácio do Paranapanema, houve uma dispersão tanto dos Kayová como dos Ñandéva que habitavam esses aldeamentos. No que diz respeito especificamente aos Ñandéva de Pirapó e de Santo Inácio, TOMMASINO (1995), baseada nas informações de Nimuendajú, destaca que eram descendentes dos Apapocúva, tendo como procedência o Mato Grosso e o Paraguai. Em suas próprias palavras:

"Havia também o Aldeamento do Paranapanema ou Santo Inácio do Paranapanema, onde viviam segundo Boutin, em 1866 índios Kayoá e Guarani. Embora Boutin não explique a origem dos Guarani, pelos documentos pesquisados, principalmente os relatórios dos exploradores Lopes e Elliot, havia vários grupos Guarani vivendo nas florestas da região. (...) os Guarani eram remanescentes dos Apapocuva que tinham saído de Mato Grosso e Paraguai em busca da Terra Sem Mal e que foram impedidos pelas autoridades paulistas de seguirem seu caminho. Alguns grupos se dispersaram livremente, outros foram instalados nas reservas criadas para os Kaingang no interior do Estado de São Paulo (P.I. Araribá) e depois transferidos para os postos do Paraná." (TOMMASINO, 1995, p.143) 
Por outro lado, a análise da composição da população de algumas das áreas indígenas do Paraná demonstra que, em determinadas AIs, os habitantes de maior idade são provenientes justamente do Posto Araribá.

Este é o caso das AIs Laranjinha e Pinhalzinho. Em seu levantamento preliminar sobre populações Guarani que falam o dialeto Ñandéva, realizado em 1990, o lingüista Robert Dooley pôde perceber que, dentre os habitantes destas duas áreas indígenas, o padrão das pessoas que dominam o dialeto Ñandéva é o de uma pessoa com aproximadamente 55 anos de idade, e que, dentre as pessoas desta faixa etária que sabiam especificar sua procedência, havia várias pessoas do Posto Araribá e do Mato Grosso do Sul. (DOOLEY, 1990)

Além disso, ao analisar o dialeto falado pelos Ñandéva de Laranjinha e de Pinhalzinho, e compará-lo com o Ñandéva Apapocúva registrado por Nimuendajú, Dooley chegou à conclusão de que as diferenças existentes entre os dialetos são tão pequenas a ponto de permitirem afirmar com segurança que, de fato, essas pessoas são descendentes dos Apapocúva, estudados por Nimuendajú há mais de setenta anos.

No que diz respeito aos Guarani de Ocoí (AI localizada mais o oeste do Paraná), os trabalhos de ROCHA (1991; 1996) contêm informações bastante relevantes. Segundo a autora, os Ñandéva de Ocoí se autodenominam "Avá-Guarani" (homem guarani), designação muito próxima à de "Ñandéva", que significa "o que somos nós", "os que são dos nossos". Localizados mais a oeste do estado, esta população teria ocupado o vale do rio Paraná desde tempos imemoriais.

"A posse imemorial é aquela onde um povo vive há tantos anos numa região, que a memória já não alcança o tempo primeiro de chegada ali. Um território onde viveram, morreram e estão enterrados os avós dos avós dos avós. Assim é o território Avá-Guarani às margens do rio Paraná. Antes que se formassem os países Argentina, Paraguai e Brasil (onde ele se insere), eles (os Guarani) já estavam ali. Antes que se estabelecessem as primeiras fronteiras coloniais, antes mesmo que se desse nome a esse continente de 'AMÉRICA', e que se passasse a chamar o povo que aqui estava no tempo da invasão de 'ÍNDIOS'". (ROCHA, 1991, p.20)

Elaine Pereira Rocha destaca que durante a realização de sua pesquisa pôde constatar, através de relatos dos componentes do grupo, que existiam ao menos oito tekoa Avá-Guarani na região. Todavia, com a recente colonização dessa região do Paraná eles tiveram suas ocupações reduzidas a uma única, por eles denominada Ocoí.

"Durante as pesquisas junto à comunidade, os AváGuarani se reuniram e, num desenho, localizaram seu território tradicional entre o rio Iguaçu e o rio Ocoí, nomeando os seguintes tekoha: Jacutinga, Porto Irene, Porto Stamato, Passo Kuê, Itaipyte (ou Porvenir), Vitor Assi, Lope'í e Guarani Kuê. (...) O que era um vasto território com muitas comunidades (...) foi gradativamente se reduzindo pela ação violenta do colonizador.
Os Avá-Guarani foram obrigados a recuar, as fontes oficiais e os relatos de membros da comunidade permitem recompor com segurança a localização de no mínimo oito TEKOHA na margem brasileira do rio Paraná no início deste século (..). Em menos de um século de colonização efetiva, a população AváGuarani se viu como que encurralada em um único TEKOHA, onde a população decaísse; e o cerco dos brancos e a depredação do meio ambiente tornou-os pobres e com poucas esperanças no devir." (idem, 24 e 10)

Se já não bastasse a redução a uma área bastante restrita, o tekoa Ocoí — último reduto desse grupo - foi inundado pelo lago de Itaipu em 1982;16 os Avá-Guarani ficaram restritos a uma região extremamente reduzida. "A terra para onde a comunidade foi transladada é uma espécie de península, uma estreita faixa de terra que margeia parte do lago da Itaipu por um lado, e é cercada pelas monoculturas dos colonos por outro." (idem, p.30) Esta área indígena passou a ser denominada Avá-Guarani.

Depois de muita luta dos Ñandéva de Ocoí, em 1966 a Itaipu Binacional cedeu um terreno localizado no município de Diamante do Oeste para o grupo, que o denominou Tekoa-Añetete. Porém, parte do grupo ainda permanece na AI Avá-Guarani.

Enquanto se têm informações mais precisas sobre as populações de Laranjinha, Pinhalzinho Ocoí e Tekoa-Añetete, o mesmo não ocorre em relação às populações Ñandéva das demais AIs do Paraná. Infelizmente, ainda não há registros ou estudos específicos que possam dizer sobre sua procedência. A própria FUNAI não dispõe de qualquer registro que possa balizar esta pesquisa no sentido de identificar a procedência desses grupos.

Essa precariedade de informações sobre grande parte dos grupos indígenas existentes no Estado do Paraná acaba por dificultar a elaboração de uma quadro mais detalhado sobre eles. No entanto, com base nas informações de que se dispõe até o presente momento, é possível o estabelecimento de algumas hipóteses para procurar, ao menos em parte, estabelecer uma visão de conjunto.

Como fora demonstrado anteriormente, ${ }^{17}$ recorrendo ao trabalho de NIMUENDAJÚ (1987), as migrações Ñandéva ocorridas no final do século XVIII e início do século XIX, que tinham como seu objetivo alcançar a Terra sem Mal, tiveram que enfrentar dificuldades de várias ordens. Mesmo que cada grupo tenha vivido situações distintas em relação a essas dificuldades - alguns conseguindo obter êxito em seus deslocamentos, chegando através deles ao litoral, outros tendo seu objetivo totalmente impossibilitado pelas barreiras que lhes foram impostas - , quando se pensa nas migrações Ñandéva como um todo pode-se dizer, de uma maneira geral, que provavelmente os Ñandéva das demais AIs do Paraná (São Jerônimo, Barão de Antonina, Ivaí, Faxinal, Rio das Cobras e Rio Areia) também sejam remanescentes dos grupos que migraram do Mato Grosso e do Paraguai, no período delimitado por Nimuendajú. Esta hipótese poderá ser colocada à prova a partir da realização de novos estudos sobre essas populações específicas. 
No entanto, ainda que esta tarefa se constitua uma etapa a ser implementada em um próximo trabalho, no que diz respeito às AIs São Jerônimo e Barão de Antonina deve ser levado em conta que pesquisadores que estiveram estudando sua população possuem informações seguras sobre a existência de parentesco e consequiente rede de sociabilidade entre as populações Ñandéva dessas áreas e as populações das áreas Laranjinha e Pinhalzinho, o que, de certa forma, pode ser interpretado como um elemento positivo para a confirmação da hipótese acima formulada.

\section{CONSIDERAÇÕES FINAIS}

A carência de informações sobre os Guarani presentes no Paraná, que pôde ser constatada durante a realização deste trabalho, indica a necessidade de que sejam realizadas pesquisas específicas sobre essas populações, à medida que se colocam novas questões e necessidades como, por exemplo, em relação aos Mbyá: qual a procedência dos grupos Mbyá da Área Indígena Rio de Areia I e II?

No que diz respeito aos Ñandéva, é necessário comprovar com maior precisão a hipótese formulada neste trabalho sobre a procedência dos grupos dessa parcialidade Guarani. Existe uma significativa possibilidade de que a população das áreas indígenas São Jerônimo, Barão de Antonina, Ivaí, Faxinal, Rio das Cobras e Rio Areia, assim como já comprovado para a população das áreas Laranjinha e Pinhalzinho, também sejam remanescentes dos grupos, descritos por Nimuendajú, que migraram do Mato Grosso e do Paraguai rumo ao leste, a partir do final do século XVIII, e que, devido a vários impedimentos, teriam se fixado, entre outros locais, no interior do Estado do Paraná.

Nesse caso, novas investigações poderiam averiguar a veracidade dessa hipótese, e, em caso afirmativo, poderiam também identificar de quais grupos a população das áreas Ñandéva, acima indicadas, seriam remanescentes, se dos Apapocuva, dos Tañyguá ou dos Oguauíva.

Sobre as populações Kayová presentes no Paraná, há necessidade de pesquisas específicas, uma vez que até o presente momento não foram objeto de qualquer investigação dessa natureza.

Como foi exposto acima, o campo para estudos sobre os Guarani presentes no Estado do Paraná é bastante amplo, e a realização de novas pesquisas nesta área é uma tarefa que se impõe. Assim, este trabalho certamente se constitui o primeiro passo para a realização de novas etapas que possam contribuir para uma melhor compreensão dos grupos Guarani presentes no território paranaense.

\section{NOTAS}

\footnotetext{
Devido à exiguidade do espaço destinado a este artigo, algumas questões que dizem respeito à cosmologia Guarani. foram suprimidas. Para uma visão mais ampla sobre esta temática, vide ROSA (1997).

2 Segundo DOOLEY (1991), se fossem considerados não apenas os grupos indígenas, mas os dialetos Guarani falados em território brasileiro, seria
}

necessário acrescentar o dialeto Avañeém (Guarani Paraguaio), que é falado em regiões próximas ao Paraguai.

3 Existem variações lingüísticas para a grafia dos termos Guarani, tais como: Nhandeva, Ñandeva, Ñandéva; Caiuá, Caiová, Kaiova, Kaiowá, Kayoá, Kayová, Kayowá, Kaiwa; Mbya, M’byá e Mbyá. Neste trabalho optou-se por adotar a grafia que tem sido mais utilizada pelos pesquisadores contemporâneos.

4 Como já destacado anteriormente, em relação à não-aplicabilidade da teoria da aculturação, este tipo de conclusão deve ser relativizado. É possivel que autores recentes, como Ruben Tomaz de Almeida e Antônio Brant, que vêm estudando o fenômeno do suicídio dos Kayová, tragam atualizações. Entretanto, pelas limitações já destacadas, não foi possível ter acesso aos seus trabalhos.

5 Para maiores informações sobre esta distinção, vide MARTINS (1986), RAMOS (1986) e SEEGER \& CASTRO (1978).

6 Assim como os demais termos Guarani, existem variações para o termo "tekoa". Neste trabalho optou-se pela grafia mais contemporânea.

7 Existem poucas informações a respeito das populações Guarani-Carijó. Segundo Noelli, "A questão da escravização dos Carijó, de fato, ainda está em aberto, sem conclusões embasadas por toda a documentação existente. Atualmente, a pesquisa mais ampla é a de John Monteiro". (NOELLI, ([199-]), p.5)

8 Cabe ressaltar que, durante o século XVI, o domínio territorial Guarani compreendia uma ampla região que engloba os atuais territórios do Paraguai e de praticamente todo o litoral sul do Brasil, como destacado por SAGUIER: "Antes da chegada dos europeus, os Guarani integravam a grande família, ou a nação conhecida com o nome de Tupi-Guarani. A mesma ocupava uma vasta região que, de maneira descontínua descia pelas costas do Oceano Atlântico desde a desembocadura do Amazonas até o estuário Platino, estendendo-se rumo ao interior até os contrafortes andinos, especialmente em volta dos rios. A família Tupi-Guarani habitava, pois, grande parte dos atuais territórios do Brasil, Paraguai, Argentina, Uruguai, Guiana, Bolívia, Peru e Equador. O núcleo guarani propriamente dito se centrava entre os rios Paraná e Paraguai com certas prolongaçôes; pode-se dizer que os guarani de Mato Grosso e parte da costa Atlântica, no Brasil e a província de Misiones na Argentina, com algumas fixações em território boliviano pelo noroeste e Uruguai pelo sudeste." (SAGUIER apud LADEIRA, 1992, p.46 - grifos meus) Essas afirmações são corroboradas pelas de CLASTRES (1978), segundos as quais "Os Tupi ocupavam a parte média $e$ inferior da bacia do Amazonas e dos principais afluentes da margem direita. Dominavam uma grande extensão do litoral Atlântico, da embocadura do Amazonas até Cananéia. Os Guarani ocupavam a porção do litoral compreendida entre Cananéia (SP) e o Rio Grande do Sul; a partir daí, estendiam-se para o interior até aos rios Paraná, Uruguai e Paraguai. Da confluência entre o Paraguai e o Paraná, as aldeias indígenas distribuiam-se ao longo de toda a margem oriental do Paraguai e pelas duas margens do Paraná. Seu território era limitado ao norte pelo Rio Tietê, a oeste pelo Rio Paraguai. Separado deste bloco pelo Chaco, vivia outro povo Guarani, os chiriguano, junto às fronteiras do Império Inca." (CLASTRES, apud LADEIRA 1992, p.44 - grifos meus)

9 Ao se deter sobre a historicidade das populações Kaingáng no Estado do Paraná, MOTA (1994) demonstrou que, em grande parte da historiografia deste estado está presente a concepção de que as terras paranaenses eram devolutas na época em que foram colonizadas. Este pesquisador denominou esse discurso ideológico como "mito do vazio demográfico", em virtude de que, ao ignorar a existência das populações pré-colombianas, possibilitou, por um lado, apagar da história as longas lutas travadas por povos tais como os Kaingáng, que procuraram resistir por séculos ao processo de penetração e ocupação dos seus territórios - buscando proteger não somente a posse de suas terras, mas, também, e conseqüentemente, a sua própria cultura --; e por outro, enaltecer a figura dos colonizadores ou pioneiros que supostamente teriam sido portadores de uma conduta ilibada e prestado grandes préstimos ao país, ao estender a civilização às terras pretensamente desocupadas do Estado do Paraná.

10 Segundo NOELLI ([199-]), p.4), "Tupiniquim" era a autodenominação dos Tupinambá de São Paulo.

${ }^{11}$ Os dados apresentados por WACHOWICZ (1988) perfazem um total de treze reduções no Guairá, porém, no trabalho de MONTEIRO (1994) menciona-se a existência de quinze reduções nesta região.

${ }^{12}$ Vide página 36.

${ }^{14}$ De acordo com o posicionamento de LADEIRA (1990; 1992; 1996), assim como de outros autores, em virtude de que todos os Guarani compunham uma mesma tribo-nação, os grupos que atualmente reivindicam a posse 
das terras de que necessitam para o seu "modo de ser" — dentre estes, os Mbyá - as reivindicam através do seu "direito" de reocuparem parte, ainda que diminuta, das terras que pertenceram a seus antepassados.

15 A pesquisa de Pires foi realizada em 1975.

${ }^{16}$ Para maiores informações sobre a complexa problemática da instalação da Itaipu Binacional vide o trabalho de ROCHA (1996) no qual ela analisa as três diferentes óticas existentes, a dos agricultores que tiveram suas terras inundadas, a dos Avá-Guarani que também perderam seu território e a do Estado.

17 Vide página 43

\section{REFERÊNCIAS BIBLIOGRÁFICAS}

ANAÍ-PR-ASSOCIAÇÃO NACIONAL DE APOIO AO ÍNDIO. Índios do Paraná: texto base para o ensino de $1^{\circ}$ e $2^{\circ}$ graus. Curitiba: ANAÍ, 1983

BOUTIN, L. "Colônias indígenas na província do Paraná". Boletim do Instituto Histórico Geográfico e Etnográfico Paranaense, Curitiba, v.36, 1979.

CEDI-CENTRO DE ESTUDOS E DOCUMENTAÇÃO INDÍGENA. Povos indígenas no Brasil 1991-1995. São Paulo: Instituto SócioAmbiental, 1996.

CLASTRES, Hèléne. Terra sem mal: o profetismo tupi-guarani. São Paulo: Brasiliense, 1978.

DOOLEY, Robert A. Breve relatório de visita aos ñandéva guarani no norte do Paraná. Brasilia: Summer Institute of Lingüistics, 1990.

Apontamentos preliminares sobre ñandéva guarani contemporâneo. Brasília: Summer Institute of Linguistics, 1991. (Arquivo Lingüístico)

ELLIOT, J.H. "A emigração dos cayuaz". Revista do Instituto Histórico e Geográphico do Brasil, Rio de Janeiro, n.19, p.434-474, 1856.

FUNAI-FUNDAÇÃO NACIONAL DO ÍNDIO. Os povos indigenas do Paraná. Curitiba, 1997.

GARLET, I.J. Mobilidade mbyá: história e significação. Porto Alegre, 1997. Dissertação (Mestrado em História Ibero-Americana) - Pontifícia Universidade Católica.

LADEIRA, Maria Inês. Espaço mbya entre as águas ou o caminho aos céus: os índios guarani e as ilhas do Paraná. [s.l.]: Centro de Trabalho Indígena-CTI, 1990.

O caminhar sob a luz: o território mbya à beira do oceano. São Paulo, 1992. Dissertação (Mestrado em Antropologia Social) - Pontifícia Universidade Católica

"Os guarani na mata atlântica". In: CEDI-CENTRO DE ESTUDOS E DOCUMENTAÇÃO INDÍGENA. Povos indígenas no Brasil 1991-1995. São Paulo: Instituto Sócio-Ambiental, 1996. p.773-776.

LOMBARDI, José C. \& NAKAMURA, Miguel. Organização social da produção dos índios kaingang e guarani de Mangueirinha: uma contribuição à discussão da problemática agrária. Limeira: Instituto Superior de Ciências Aplicadas-Depto. de Ciências Humanas, 1981.

MARTINEZ, N.D. "La migration mbya (guarani)". Dédalo, São Paulo, USP, n.24, p.148-167, 1985.

MARTINS, J. de S. Não há terra para plantar neste verão: o cerco das terras indígenas e das terras de trabalho no renascimento político do campo. Petrópolis: Vozes, 1986. p.36.

MELIÀ, Bartolomeu. "El guarani conquistado y reducido: ensayos de etnohistoria". Biblioteca Paraguaya de Antropologia. v.5. Asunción: Centro de Estudios Antropológicos de la Universidad Católica, 1993.

MONTEIRO, John Manuel. Negros da terra: índios e bandeirantes nas origens de São Paulo. São Paulo: Cia. das Letras, 1994

MOTA, Lúcio Tadeu. As guerras dos índios kaingáng: a história épica dos índios kaingáng no Paraná (1769-1924). Maringá: UEM, 1994.

NIMUENDAJÚ, Curt. As lendas da criação e destruição do mundo como fundamento da religião dos apapocuva-guarani. São Paulo: HUCITEC/
EDUSP, 1987.

NOELLI, Francisco Silva. "A destruição dos carijó-guarani no litoral sulbrasileiro". In: ENCONTRO DE HISTÓRIA E GEOGRAFIA DO INSTITUTO HISTÓRICO E GEOGRÁFICO DO RIO GRANDE DO SUL Anais... [s.1.] [199-].

PIRES, Maria Lígia Moura. Guarani e kaingáng no Paraná: um estudo de relações intertribais. Brasília, 1975. Dissertação (Mestrado em Antropologia Social) - Universidade de Brasília.

RAMOS, Alcida R. Sociedades indígenas. São Paulo: Ática, 1986

ROCHA, Elaine Pereira. Avá-guarani presente!!! Xanxerê: CIMI-CONSELHO INDIGENISTA MISSIONÁRIO-Regional Sul, 1991

Canal de desvio: um estudo da experiência de agricultores e índios no confronto com a Itaipu Binacional. São Paulo: 1996. Dissertação (Mestrado em História) - Pontifícia Universidade Católica

RODRIGUES, Ayron D. "A língua dos índios xetá como dialeto guarani". Cadernos de Estudos Lingüísticos, n.1, São Paulo, 1978.

Línguas brasileiras: para o conhecimento das línguas indígenas. São Paulo: Loyola, 1984.

ROSA, Marcelo Caetano de Cernev. As parcialidades guarani no Paraná: elementos de cosmologia e história. Londrina, 1997. Monografia (Especialização em Sociologia e Sociologia da Educação) - Universidade Estadual de Londrina.

ROSSATO, Márcia. Semana do índio. Curitiba: FUNAI/SUER-1ª Região, 1987.

SCHADEN, Egon. Aspectos fundamentais da cultura guarani. São Paulo: DIFEL, 1962.

SEEGER, Anthony \& CASTRO, Eduardo B.V. "Terras e territórios indígenas no Brasil". Encontros Com a Civilização Brasileira, Rio de Janeiro, n.12, 1978.

TOMMASINO, Kimiye. A história dos kaingáng da bacia do tibagi: uma sociedade Jê meridional em movimento. São Paulo, 1995. Tese (Doutorado em Antropologia Social) - Universidade de São Paulo.

WACHOWICZ, Ruy Christovam. História do Paraná. 6.ed. Curitiba: Vicentina, 1988. 